\title{
光環境の活動性印象と光の空間的分布特性との関係 RELATIONSHIP BETWEEN ACTIVE-CALM EVALUATION AND SPATIAL DISTRIBUTION OF LIGHT IN LIGHTING ENVIRONMENT
}

\author{
山 路 英 洋*, 石田 泰一郎** \\ Hidehiro YAMAJI and Taiichiro ISHIDA
}

\begin{abstract}
The purpose of this study was to examine relationship between physical elements and psychological evaluation of lighting space. The study was made using an actual-size space, which were equipped with various luminaries. Subjects evaluated interior ambience generated from various light distribution. We investigated the relationship between active-calm evaluation and characteristics of light distribution, especially its spatial arrangements, and showed that the number of peaks of light distribution and luminance contrast between peak and its peripheral area can be used for estimating active-calm evaluation.
\end{abstract}

Keywords: interior ambience, light environment, activity, luminance distribution 室内䨌囲気、光環境、活動性、輝度分布

\section{1.はじめに}

光環境の質を決定する要因は大きく二つに分類することが出来る。 一つはその機能性である。対象物がはっきりと見えるかといった明 視性や非常に高い輝度の部分が直接視界に入らないかといったグレ アの問題がこれに含まれる。機能面に関する問題は定量的に検討し やすく研究も多く行われており、JS 照度基準などその成果に基づ く設計指標が提案されている。これらの指標に基づいて設計を行え ば、ある程度の機能性を持った光環境を設計できることになる。

もう一つは場にふさわしい雾囲気を実現しているかといった雾囲 気性に関するものである。精神的な豊かさを求める時代背景も伴い、 重要となりつつある側面である。多種多様な用途に適した光環境を 実現するうえでは、雾囲気性に関する設計・評価の為の定量的指標 が必要であると考えられるのだが、現在のところそのような指標は 存在しない。

雲囲気性に影響を与える要因の一つに様々な光源の配置によって 産み出される光の分布状態があり、いくつかの研究においてその関 連性が定性的に示されている 1) 3)。これに基づいた指標を作成する には光の分布状態を量的に示すことが必要であり、このような研究 も行われている4) ののだが、指標を提案するには至っていない。

Loe ${ }^{4)}$ はこのような問題に取り組んだ 1 人であり、輝度分布の統計 量によって光の分布状態を表すことを提案している。彼はリビング 空間において様々な照明条件を呈示し印象評価実験を行い、視覚的 面白さの評価と上下 $40^{\circ}$ 水平帯の輝度の標準偏差との対応を示し
た。このように光の分布を量的に表す試みには輝度值の累積分布の 基本統計量を用いるものが多いが、統計量によって光の分布状態を 全て表現できるわけではない。表現できないものの一つが空間的な 情報である。その例を図 1 に示す。これは平面に光があたっている 状態を模式的に示し、輝度値の出現頻度ヒストグラムがほほ同じと なるように作成したものである。従って基本統計量の值は等しくな る。しかし空間的分布に関しては異なっている。輝度の高い部分が 図aではまとまって存在し、図 cでは散らばって存在する。また図 b ではそれが下部に集中しているのである。このような位置情報の 重要性について言及した研究もある $\left.{ }^{6}\right)$ が、雾囲気性の指標として明 確に取り入れられるまでには至っていない。雾囲気性には局所光の 与える影響が大きく、指標化の際にはこのような光の空間的分布状 態を表すことが重要ではないかと考えている。

以上のような考察を元に、筆者は雾囲気性について広く適用可能 な評価・設計指標を提案する事を目的とした研究を行っている。

また雾囲気性については、特に落ち着きにぎやか、静的/動的と いった活動性印象を扱っている。これは光環境の印象評価に関する 研究報告において頻出する ${ }^{899)}$ 評価因子であり、実際の適用面でも有

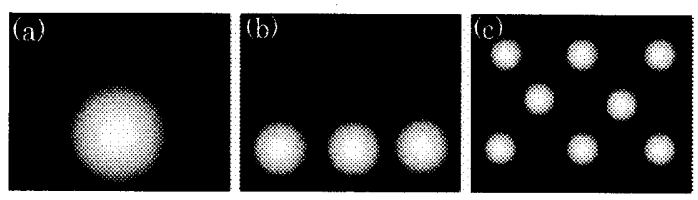

図 1 光の空間的分布の例 (全て同ビヒストグラムとなる)
* 京都大学大学院工学研究科 大学院生 $\cdot$ 修士 (工学)

** 京都大学大学院工学研究科 助教授. 工博
Graduate Student, Graduate School of Engineering, Kyoto University, M. Eng. Assoc. Prof., Graduate School of Engineering, Kyoto University, Dr. Eng. 
用であると考えた為である。

筆者は以前、模型実験により光源の数、配光(光の搪がり)、光源 の上下位置が活動性印象と関連する照明要因(光の分布状態に影響 を与える)であるという結果を得ている注1。但し縮尺模型で行った 実験をもとにしているため、上記の結果が人が空間内部において光 の分布を感じ取るような実空間でも成り立つかは不明である。そこ で本実験では実大空間中にこれらの照明要因に着目した条件を呈示 し、活動性印象をはじめとする印象評価実験を行う。また、その結 果をもとに活動性印象に関する指標を提案する事を試みる。

\section{2 実大空間による実験}

\section{2-1 実験内容}

実大空間内に様々な照明条件を呈示し、被験者による印象評価実 験を行う。実験は図 2 に示す幅 $2.4 \times$ 奥行 $3.0 \times$ 高さ $2.4 \mathrm{~m}$ の害大空 間で行った。内装として、壁・天井には一様白色の壁紙（反射率 $\rho$ $\doteqdot 0.75)$ を、床には濃灰色 $(\rho \doteqdot 0.10)$ のカーペットを用いた。実大 空間内には様々な配光特性を持ち、奥壁面を照明する光源 7 基(記号 $\mathbf{a} \sim \mathbf{f}, \mathbf{W})$ と空間内全体を拡散光で満たす天井光(記号 C)を設置した

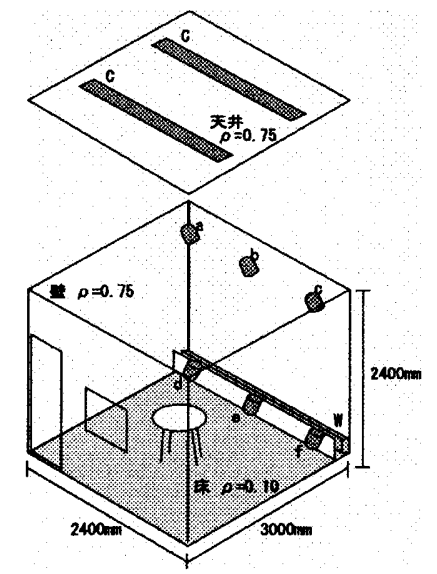

図 2 実験に使用した実大空間

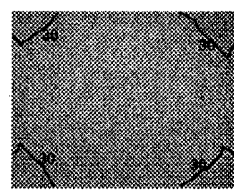

C 天井光

$40 \mathrm{~W}$ 白色蛍光灯 8 本 色温度 : $6700 \mathrm{~K}$

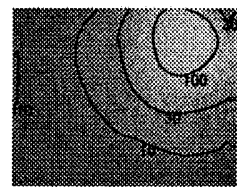

c スポットライト

$80 \mathrm{~W}$ 白熱電球

色温度 : $2800 \mathrm{~K}$

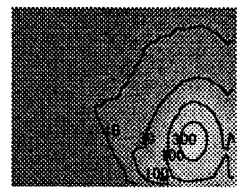

f スポットライト $80 \mathrm{~W}$ 散光型白熟電球 色温度: $3000 \mathrm{~K}$

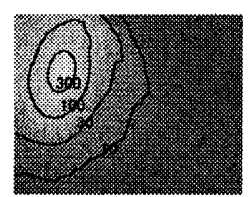

a スポットライト 80W 散光型白熱電球 色温度 : $3000 \mathrm{~K}$

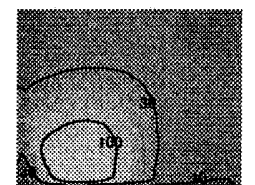

d スポットライト $80 \mathrm{~W}$ 白熱電球 色温度：2800K

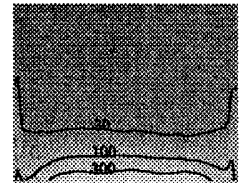

W ウォールライト 20W 白色蛍光灯 3 本 色温度：5000K

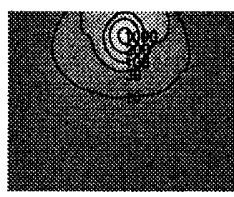

b スポットライト $50 \mathrm{~W}$ ハロゲン電球 色温度 : $3200 \mathrm{~K}$

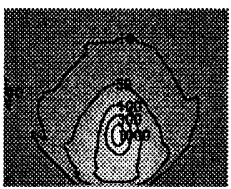

e スポットライト 80 W 集光型白熱電球 色温度：3000K

*各光源を一灯たけ点灯 したときの奥面の輝度 分布コンタープロット (単位 $\mathrm{cd} / \mathrm{m}^{2}$ )
（図 3）。各光源は設置位置においても互いに異なっている。また、実 大空間の手前面には被験者の出入り、輝度分布の計測に用いるため の開口を設けているが、実験時これらは暗幕によって塞いでいる。

実験者は各光源の ON/OFF の組合せによって様々な照明条件の 呈示を行う。被験者は室中央の椅子に座り前方を眺め、奥壁面の光 の状態を主な手掛りとして照明空間に対する印象を様々な項目につ いて回答する。天井光については ONとした時に被験者の顔位置(休 上 $1.4 \mathrm{~m}$ )での水平面照度が約 $300 \mathrm{~lx}$ になるように設定した。評価項 目は明暗・活動性・評価性の計 3 項目(表 1)であり、各項目につい て両極 5 段階スケールによって回答を行う。活動性については意味 性や価值判断といった側面を抑えた形容詞「静的一動的」を用いた。 また、各項目の評価点は連続量として取り扱う。

呈示する照明条件は光源 $\mathrm{a}$ ～ $\mathrm{f}, \mathrm{W}$ の点灯パターンを変化させた 20 条件に天井光 C の ON/OFF のパターンを加え全般照明レベルを変 化させた計 40 条件である。呈示条件のプロファイルといくつかの 例を図 4 に示す。条件設定の際には各スポットライトの配光を目視 によって 3 つの定性的カテゴリ(緩やかな光の分布となる光源、急な 光の分布となる光源、その中間)に、設置位置を 2 つのカテゴリ(上 に設置、下に設置)に分類し、これを参考とした。また、各照明条件 について奥壁面の輝度分布をデジタルカメラによって計測し、以降 の検討に用いた。計測範囲は被験者位置から見て顔位置を中心とし 鉛直方向が視角 $60^{\circ}$ 、水平方向が視角 $80^{\circ}$ にお扰々相当する範 囲である。

被験者は室に入るとまず天井光を ON にした状態で 3 分間順応す る。この間に評価項目・実験手順などについてのインストラクショ ンが行われる。その後 40 の照明条件に対し前述の評価を行う。ま

表 1 評価項目
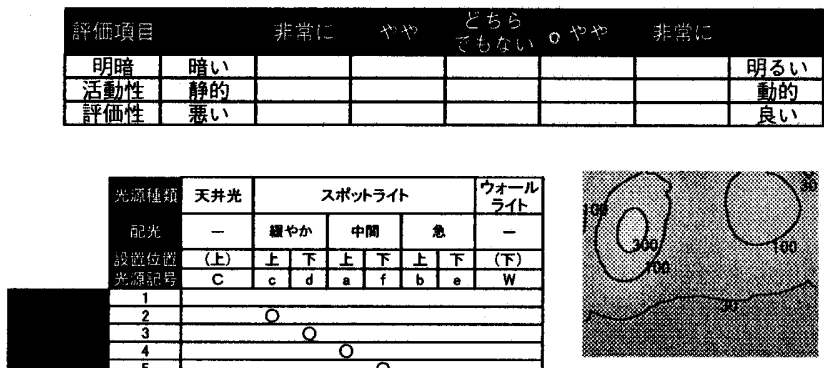

条件 9 使用光源 ac

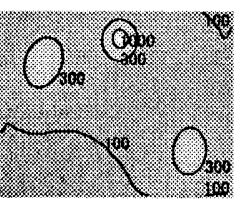

条件 36 使用光源 Cabcf

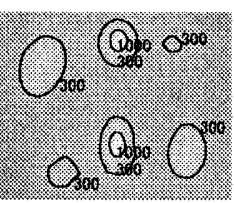

条件 39 使用光源 Cabcdef

図 3 筀間内に設置した光源 
た、最初の照明条件を呈示する直前と呈示のインターバルでは実験 空間を数秒暗黒状態とし、呈示順は被験者によってランダムに変更 した。被験者は建築系学生 10 名(男 6 名、女 4 名)であり全員が心理 物理実験の経験者である。

\section{2-2 光環境に対する印象評価}

各評価項目について被験者 10 名の平均評価スコアをプロットし たものが図 5 である。各図における縦軸は印象評価、横軸は照明条 件を表しており、横軸において同じ座標位置にあることは天井光 $\mathrm{C}$ 以外の点灯パターンが同じであることを示している。天井光を ON としたものはO、OFFとしたものはのによってプロットを行った。 照明条件は使用した光源の数(天井光、ウォールライト除く)が少 ないものに小さな条件番号を、多いものに大きな条件番号を与えた。 図 5 中条件(1,21)は 0 個、条件 $(2 \sim 7,22 \sim 27)$ は 1 個、条件(8 14,28 $\sim 34)$ は 2 個、条件 $(15 \sim 18,35 \sim 38)$ は 4 個、条件 $(19,39)$ は 6 個の光 源を使用したものであり、条件 $(20,40)$ はウォールライトのみ使用し たものである(ここで 1２0 は天井光を OFF、21４0 は天井光を ONにした条件であることを示す)。さらに、使用した光源の数が同 し場合には光源 $\mathrm{c}, \mathrm{d}$ など楥やかな配光の光源を用いるものに小さな 条件番号を与え、光源 $\mathrm{a}, \mathrm{f} 、$ 光源 $\mathrm{b}, \mathrm{e}$ と用いる光源の配光が急になる に従って大きな番号となるようにした。また、条件 2 と 3 のように 用いた光源の数が同じであり配光も似ているものの、光源の上下配 置に扔いて大きく異なる組合せも存在する。図 5 下にこれら照明条 件の詳細を示す。
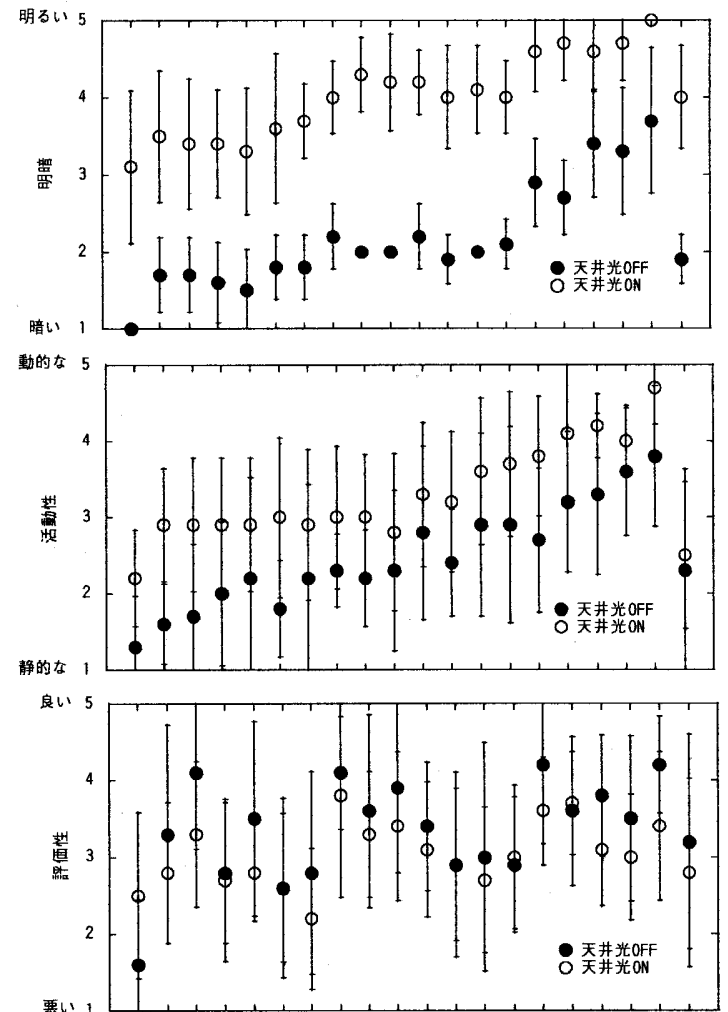

\begin{tabular}{cccccccccccccccccccccc}
\hline & 1 & 2 & 3 & 4 & 5 & 6 & 7 & 8 & 9 & 10 & 11 & 12 & 13 & 14 & 15 & 16 & 17 & 18 & 19 & 20 \\
0 & 21 & 22 & 23 & 24 & 25 & 26 & 27 & 28 & 29 & 30 & 31 & 32 & 33 & 34 & 35 & 36 & 37 & 38 & 39 & 40
\end{tabular}

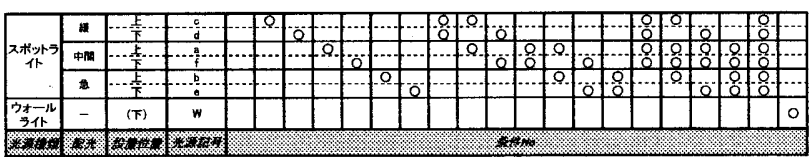

図 5 実験結果・上から順に明暗・活動性・評価性の評価
エラーバーは評価スコアの被験者間標準偏差を表したものである が、明暗・活動性・評価性の標準偏差は各条件の平均でそれぞれ 0.51,0.89, 1.00 であった。また、被験者のうち 5 名については 2 回 目の実験を行ったが、5 名の平均評価スコアはいずれの項目につい ても 1 回目のそれと強い相関 $(r>0.84)$ を示した。以下各評価項目と 照明要因について考える。

図 6 は明暗の評価スコアを再揭するものだが、○とのによるプロ ットを比べるとまず明暗の評価に天井光の ON/OFF が大きな影響 を与えている事がわかる。また、点線の矩形領域で囲んだ部分は用 いた光源の数が同じであることを示しているが、右の矩形領域にゆ くほど明るいと評価されており、用いた光源の数によって明暗の評 価が変化していることも読み取れる。ここで明るさ感の輝度分布に よる指標のうち最も一般的だと考えられる平均輝度について明暗の 評価との関係を検討すると、その相関は強くなる（図 7、 $\mathrm{R}=0.83$ )。

しかし図 7 ではおおよそ回帰直線を境として上に天井光を点灯さ せた条件、下に天井光を点灯させなかった条件が並んで㧍り、今回 の天井光のように空間全体を満たし、緩やかに変化する光が明るさ 感覚に大きく影響していることも示唆される。すなわち平均輝度が 等しくても光の分布状態によって明るさ感は異なる。これは近年の 明るさ感評価に関する研究 10) 13)から得られる知見に一致する。

図 8,9 は活動性の評価スコアを再揭するものである。まず図 8 の 矩形領域で囲んだ部分を見ると使用した光源の数によって活動性印 象が変化することがわかる。使用した光源の数が多いほど活動性は 高く、少ないほど活動性は低く評価される傾向にある。また黒矢印 は用いた光源の数が同じ場合について配光の違いに伴う活動性評価 の変化の傾向を表したものだが、それぞれの矢印が右上がりになっ ていることから、急な配光の光源を用いるほど活動性は高く、緩や かな配光の光源を用いるほど活動性は低く評価される傾向にあるこ とがわかる。さらに、○、のによプロットの比較から、天井光を 点灯し照明レベルを上昇させると活動性の評価が上昇することもわ かる。図 9 の白抜き矢印は上下配置において大きく異なる条件(その 他の条件は類似している)を結んだものであり、矢印の始点に位置

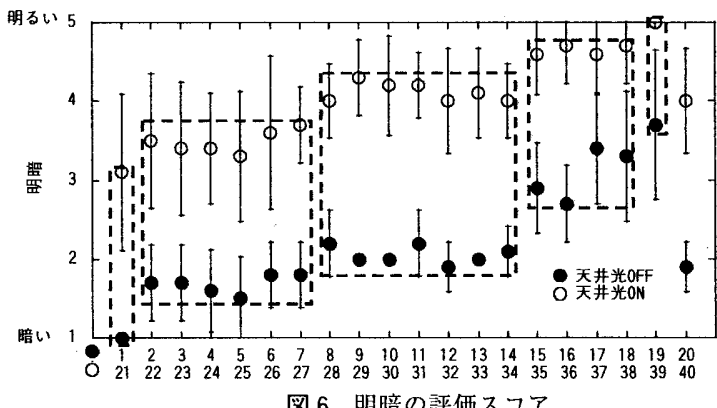
図 6 明暗の評価スコア

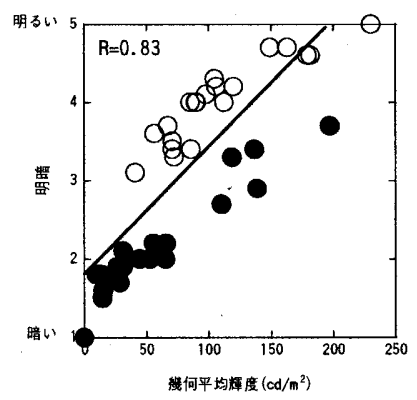

図 7 明暗の評価と平均輝度 
するものが上に設置した光源を用いる条件、終点に位置するものが 下に配置した光源を用いる条件である。によるプロットを見ると、 天井光を OFF にした場合では上下の配置によって活動性の評価が 変化し、下に設置した光源を用いる条件では活動性が高く評価され る傾向にあることがわかる。

評価性の評価スコア（良い・悪い)を再揭したものが図 10 である。 黒矢印を見るとわかるように影響する要因の一つは用いる光源の配 光であり、矢印が右下がりになっていることから緩やかな光を用い る条件で評価が高くなる傾向があることがわかる。また白抜きの矢 印を見ると、天井光を OFF にした場合では上下配置の影響もあり 下に設置した光源を用いる条件が良いと評価される傾向にあること もわかる。
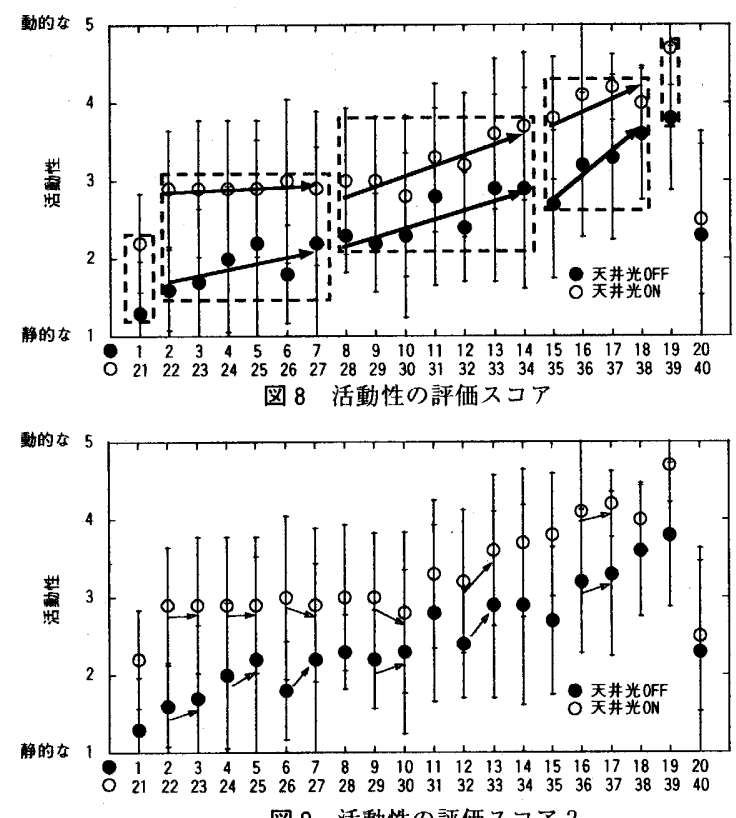
図 9 活動性の評価スコア 2

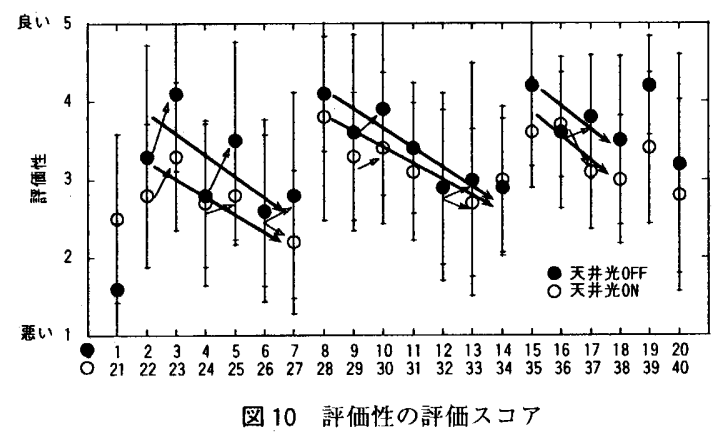

3 各要因の指標化

いくつかの照明要因について、それが活動性印象に影響を与える ことを前章で示した。これをまとめると、
a) 光源の点灯数
b）光源によってうみだされる光の分布状態（配光）
c）光源の上下配置
d）全体的な照明のレベル

のようになる。そこで本章ではこれらの結果をもとに光の空間的分 布状態に基づく指標値を作成し、活動性印象の推定式を示す。たた しこのうち d)全体的な照明のレベルについては明視性など空間に
要求される機能によって決まる側面が大きいと考えられるため、雾 囲気性に注目する今回はカテゴリとしての扱いに留め、説明変数と しては扱わない。

まず、a)光源の点灯数は活動性評価に関わる大きな要因であった。 ここで各照明条件の輝度分布をみると多くの光源を点灯させると輝 度分布に多くの山ができる様子が認められた。そこで輝度の局所的 な分布に着目し周囲より輝度の高い分布の山の数を数える。具体的 には図 11 に示されているようにこれを求める。すなわち、得られ た輝度分布画像を縦 8 横 8 の矩形領域に分割し、ある領域内の平均 輝度がその領域と頂点を共有する近傍 8 領域の平均輝度のいずれよ りも高い場合、これを輝度のピーク領域とし、この数 $N$ を求める。 $N の$ 值は実際に使用した光源の数に関連し、多くの光源を用いるほ ど大きな值となる傾向があった。 $N$ と活動性評価との関係を天井光 を ONにした場合、OFFにした場合に分けて図 12 に示す。Nの値 が大きくなるに徥って活動性評価が上昇する様子がみてとれる。

またb)光源の配光も影響する要因であった。ここで、各照明条件 の輝度分布をみると、配光の急な光を用いると輝度分布の山が急に なり、緩やかな光を用いると山が䋸やかになる様子が認められた。 そこで図 13 に示すように各ピーク領域についてピーク領域とその 近傍 8 領域の輝度比を求め対数值に変換し、ピーク領域間の平均値 をとりピーク領域近傍輝度比 $L C$ とした。 $L C$ の值は実際に使用し た光源の配光に関連し、用いる光源の配光が急であるほど大きな值 となる傾向があった。 $L C$ と活動性評価との関係を図 14 に示す。 $L C$ の値が大きくなるに従って活動性評価が上昇する様子が見てとれる。 c)光源の上下配置は上下領域の輝度比 $C u l$ (輝度分布画像の鉛直 中央を境とした上側の平均輝度を下側の平均輝度で割り、対数をと る）によって指標化する。Cul の值は光源の上下配置に関連し、上 に設置した光源を用いると大きな值となる傾向があった。活動性印 象との関係を図 15 に示す。Cul の值が大きくなると活動性評価が 低下する傾向もみられるが、活動性評価との相関は弱くなっている。 ここで、 $N, L C, C u l$ 相互の相関係数は低い(天井光 $\mathrm{ON}$ の場合、 OFF の場合共に全組合せで $|R|<0.10) 。$

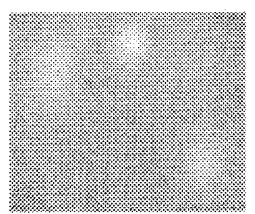

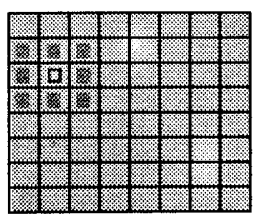

$\mathrm{D} \geqq \mathrm{AL}$ 绕

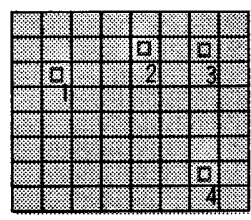

$\mathrm{N}=4$
同ビーク領域 箖 ビーク近傍領域

図 11 指標値・ピーク領域数 $N$
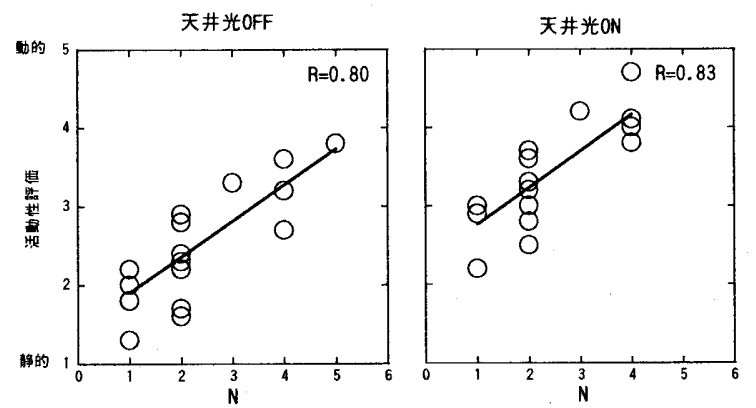

図 12 ピーク領域数 $N$ と活動性評価 
これらの要因が活動性印象に与える影響を検討するために、 $N$, $L C, C u l$ 説明変数、活動性評価を目的変数とした重回帰分析を行 った。結果が表 2 である。

標準偏回帰係数を見ると、全体的には指標値 $N, L C か ゙$ 活動性印象 に大きな影響を与えていることがわかる。また天井光 OFF の場合 には指標値 $C u l$ もやや影響する。下に配置した光源を用いる場合に 活動性評価が高まるという結果は低い位置の光源が落ち着き感を与 える 14)という照明デザインでよく知られている手法と異なる注2)が、 上記 2 つの指標值に比べるとその効果は小さく、天井光の ON/OFF によって影響の度合いも異なることから、今回は特に $N, L C$ に注目 することとする。
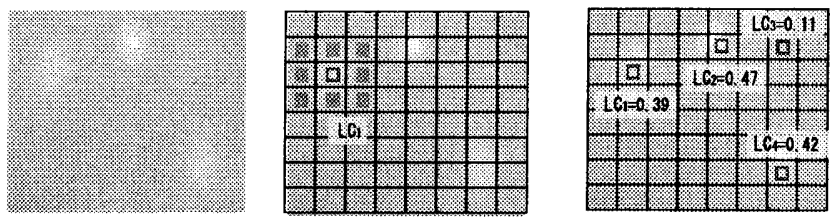

$L C_{i}=L O G(D / A V E R A G E(\$ a)) \quad L C=\frac{\sum L C_{i}}{N}(i=1 \sim N)=0.35$

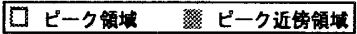

図 13 指標値・ピーク領域近傍輝度比 $L C$
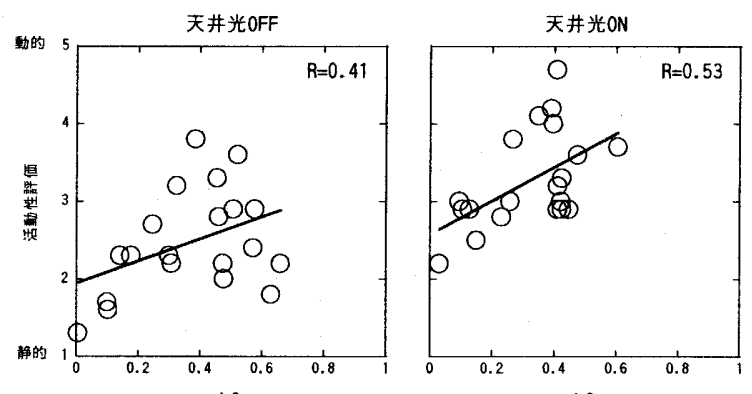

LC

図 14 活動性印象とピーク近傍輝度対比 $L C$ との関保
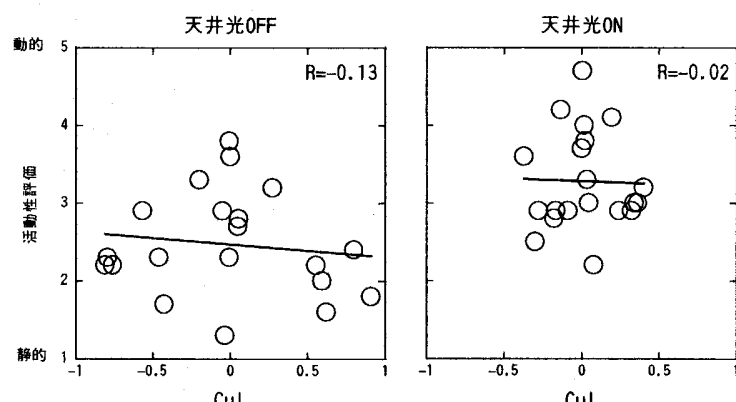

図 15 活動性印象と上下輝度比 $\mathrm{Cul}$ との関係

表 $2 N, L C, C u l$ を説明変数、活動性評価を目的変数とした重回㷌分析結果

\begin{tabular}{|c|c|c|c|c|c|}
\hline 変数名 & 偏回帰係数 & 標準偏回帰係数 & $\mathrm{F}$ 值 & $\mathrm{T}$ 值 & $\mathrm{P}$ 值 \\
\hline LC & 1.67 & 0.48 & 36.29 & 6.02 & 0.00 \\
\hline $\mathrm{N}$ & 0.48 & 0.84 & 110.82 & 10.53 & 0.00 \\
\hline $\mathrm{Cul}$ & -0.26 & -0.20 & 6.48 & 2.55 & 0.02 \\
\hline 定数項 & 0.76 & & 22.49 & 4.74 & 0.00 \\
\hline 重相関係数 & 0.95 & & & & \\
\hline
\end{tabular}

重回帰式/天井光ONの場合

\begin{tabular}{|c|c|c|c|c|c|}
\hline 変数名 & 偏回慢係数 & 標準偏回慢係数 & $\mathrm{F}$ 值 & $\mathrm{T}$ 值 & $\mathrm{P}$ 值 \\
\hline $\mathrm{LC}$ & 1.59 & 0.39 & 13.76 & 3.71 & 0.00 \\
\hline $\mathrm{N}$ & 0.43 & 0.76 & 52.80 & 7.27 & 0.00 \\
\hline $\mathrm{Cul}$ & 0.04 & 0.02 & 0.02 & 0.15 & 0.88 \\
\hline 定数項 & 1.87 & & 109.77 & 10.48 & 0.00 \\
\hline 重相関係数 & 0.91 & & & & \\
\hline
\end{tabular}

$N, L C$ と活動性印象との関係についてさらに検討する。各照明条 件の $N$ 値、 $L C$ 値、活動性評価スコアを元に、 $N$ を横軸、 $L C$ を縦 軸とした活動性評価のコンタープロットを作成したものが図 16 で ある。図ではさらに評価中間值 3 を評価の転換点と捉え、静的ある いは動的な印象を与える $N, L C$ の組合せの範囲を大まかに示した。

また、図 16 からは $N$ と $L C$ の積によって活動性評価が良く推定 できることが予想される。ここで $N$ と $L C$ の積は個々のピーク領域 に近傍領域との輝度比を得点としてあたえ、総和をとった值と解釈 できる(図 17$)$ 。今回は $L C$ の值の算出の際に単純に $N$ で平均をとっ ているため、 $N \times L C$ は実質 $\Sigma L C i(i=1 \sim N$ )で計算される值であり、 計算上 $N$ は消えてしまうことになる。ただし、2 章に示したように 光源の数は活動性印象を左右する照明要因であり、活動性評価指標 を考慮するにあたって重要な変数であると考える。この考え方を示 すため今回は $N \times L C$ と表記を行う。

$N \times L C$ を説明変数、活動性評価を目的変数として回帰分析を行い、 天井光の ON/OFF 別に結果を示したものが図 18 である。相関係数 は高く、指標值 $N \times L C$ によって活動性評価をよく推定できている ことがわかる。また、天井光の ON/OFF に伴う両回帰式の違いが主 に切片の違いであり、回誉係数は大きく変化しないことから、 $N X$ $L C$ と活動性評価との関係が照明レベルの高低によって大きく変化 しないことがわかる。ただし表 2 を見れば分かるように活動性印象 への影響の度合いは $N$ と $L C$ で異なっている。従ってより高い推定 の精度を求めるなら变数に何らかの重み付けが必要であることが考 えられる。しかし今回は重み付けを行わない $N \times L C$ という值が図 17 のように実際の物理状況から捉えやすい值であると判断したた め、これをそのまま用いた。
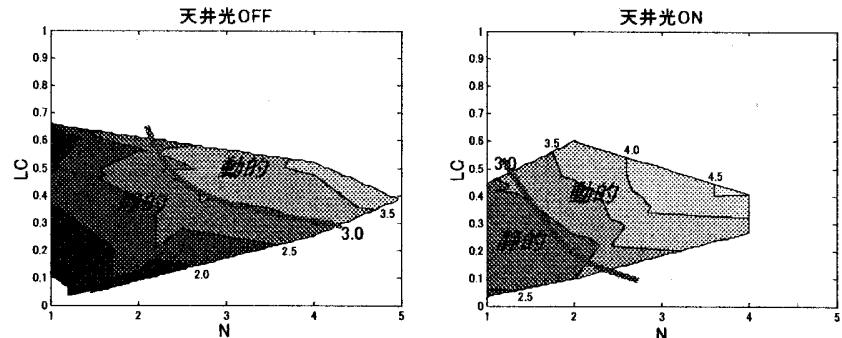

图 $16 N, I L$ の値の組み合わせと活動性棓価

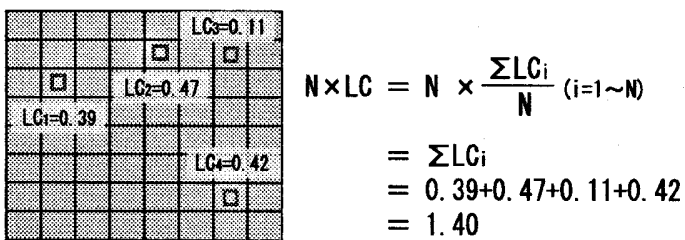

図 17 指標值 $N \times L C$
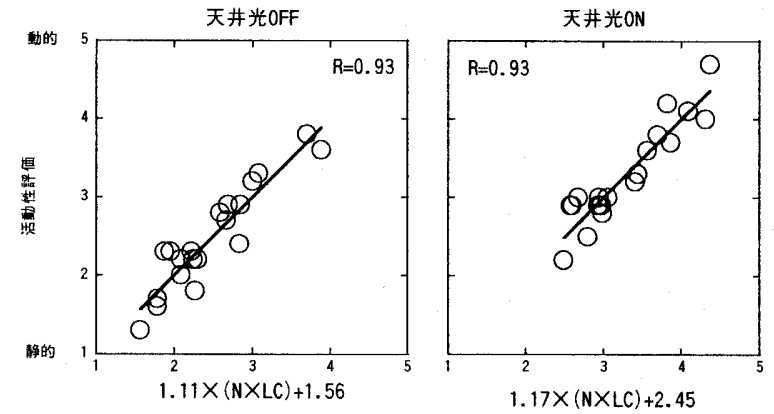

図 $18 \quad N \times L C$ と活動性印象との関係 
この指標に従えば、読書などに支障がない程度の照明レベル(水平 面照度 $300 \mathrm{~lx}$ 程度)が要求される場合に活動性の低い光環境にする ためには $N \times L C$ の值をおよそ 0.5 までに抑える必要があるという ことになる。また、全般照明を特に使用しない場合であれば、活動 性印象の高い光環境とするためには $N \times L C$ の值が 1.3 程度必要で あることになる。

また、今回は輝度分布画像を $8 \times 8$ の矩形領域に分割し $N \times L C$ を 算出しているが、この值は領域分割数によって異なると考えられる。 そこで、領域分割数を変化させ $N \times L C$ の値を算出し、活動性評価 との相関の強さを求めた。結果を図 19 に示す。横軸は領域分割数 を表しており、128×128 のように分割数が大きいほど個々の領域 は小さくなり、 $2 \times 2$ の分割では個々の領域は大きくなる。縦軸は $N$ $x L C$ の值と活動性評価との相関係数を示している。

図より、今回採用した $8 \times 8$ 分割で活動性評価と $N \times L C$ との相関 は最も高く、32×32 分割あたりまでは比較的良好な相関が得られて いることがわかる。

$8 \times 8$ 分割 $32 \times 32$ 分割で算出された $N \times L C$ の值で活動性評価が 良好に推定できたのは、それらの分割数が今回の実験条件における 照明光の分布パターンの細かさに対し適当な大きさであったためで あると考えられる。これより粗い分割では個々の領域が大きくなり すぎ、複数の分布の山が同じ領域に含まれるなどのため、照明光の 分布の特徵を捉えるのに適さなかったと考えられる。一方、より細 かく分割すると分布の勾配の違いを表現することが難しくなり、ま た壁の凹凸の影響もあらわれ、照明光の分析には適さなくなったと 考えられる。

このように領域分割数は照明の分布の特徽を適切に表現するよう に定める必要があるが、それを一般的に決定するための方法は本論 文の段階では定式化できていない。そのためには、照明条件や観察 距離などの状況によって変化する照明光の分布パターンの細かさに 応じた算出方法の検討が必要となり、今後の検討課題の一つである。

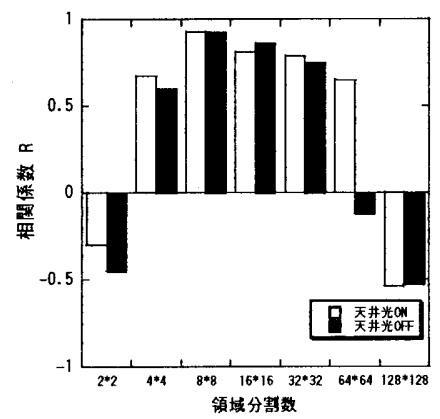

図 19 領域分割の大きさを変更し算出した $N \times L C$ の値と活動性印象との 相関関係の強さ

4 まとめ

実大空間に様々な照明条件を呈示し、被験者にその光環境に対す る活動性印象を評価してもらった。実験結果から光源の数などいく つかの照明要因についてそれが活動性印象に関連することを示した。 次にこれらの結果を手掛りとして輝度の空間的分布特性によって 活動性を推定する指標値を作成することを試みた。作成した指標値 は活動性印象を精度よく推定できるものとなっており、(輝度分布の 領域分割を行い)ピーク領域数 $N$ とピーク領域と周辺領域との輝度 対比值 $L C$ の積 $N \times L C$ にって活動性印象を推定するという基本
的な考え方の有効性を示すことができたと考える。

今後の検討課題として 2 点挙げる。まず今回の実験では用いた実 大空間の反射率が一定であるため各照明条件の輝度分布が光の分布 に対応するものになっている。そのため、指標值 $N \times L C$ は光の分 布状態と活動性印象の関係を表したものであるということが出来る。 一方実際の空間では絵画やポスター、家具などが存在することが多 く、この場合本報告のような指標を適用すると精度よく活動性印象 を推定できない可能性が存在する。また指標値の算出方法の一般化 も課題の一つである。様々な空間に対して輝度分布の計測範囲や分 割大きさなどをどのように決定すればよいのかについて検討する必 要がある。

注

注1）平成 16 年度照明学会全国大会において同実験の報告を行った (山路、石田:平成 16 年度照明学会全国大会講演論文集 p.197)。 本文中の記述はこれにさらなる検討を加え、得られた知見であ る。

注2）模型実験でも全体的に暗い場合に活動性印象と光源の上下位 置に比較的強い関連が見られており、下に配置した光源を使用 すると落ち着いた光環境になるという照明デザイン手法と一 致する結果が得られた。今回そのような関係が見られなかった 理由の一つに形容詞として静的・動的といった形容詞を用いた ことが考えられる。对して模型実験では落ち着いた・にぎやか なといった形容詞を用いている。このような形容詞に含まれる 意味的、価值判断的な側面が光源の上下位置と関連している可 能性がある。今回の結果でも、評価性においては上下位置が大 きな影響を与えているケースが存在した。

\section{参考文献}

1) Flynn,J.E. et al:: Interim study of procedures for investigating the effects of light on impression and behavior, J. Illum. Eng. Soc. Vol.3, No.1, pp.87-94, 1973.10

2）三木保弘, 宮田紀元: 光源の配置と室内表面の構成が雾囲気に 及ほす影響一光の空間的配分に関する研究一, 日本建築学会計 画系論文集, No.488, pp.111-119, 1996.10

3）中村肇，唐沢宣典，沢辺真由美：リビング照明の心理要因と物 理要因の体系化, 照明学会誌, Vol.80, No.11,pp.811-818,1996

4) Loe,D.L. et al: A step in quantifying the appearance of a lit scene, Lighting Res. Technol. Vol.32,No.4,pp.213-222,2000

5) A Pellegrino : Assessment of artificial lighting parameters in a visual comfort perspective, Lighting Res. Technol. Vo 1.31, No.3, pp.107-115, 1999

6）中村芳樹、乾正雄：オフィスの輝度分布特性とその心理的効果, 日本建築学会計画系論文報告集, No.445,pp.27-33，1993.3

7） 中村芳樹、乾正雄：視環境の輝度分布特性に関する研究，日本建 築学会計画系論文報告集, No.438, pp.1-8, 1992.8

8）田淵義彦他 2 名：雲囲気分析に基づくりビング空間の照明技法 の開発,照明学会誌,Vol.69,No.10,1985

9）湯尻照：縮尺模型による照明条件の視環境評価に関する実験, 照明学会誌,Vol.61,No.3,pp43-50,1977

10）荻内康雄，石田泰一郎：参照マッチング法による空間の明る さ感評価の基礎的検討，照明学会誌, Vol.83, No.5, pp.295-3 95,1999

11）荻内康雄, 石田泰一郎：空間の明るさ感の心理決定要因一光 源の強さ感と空間の光量感一, 照明学会誌,Vol.84, No.8A,pp. $473-479,2000$

12）荻内康雄,石田泰一郎：仮想輝度分布法による空間の明るさ感推 定の有効性,照明学会誌,Vol.87,No.2,pp105-112,2003

13）小林茂雄他 3 名: 空間の輝度分布が室内の明るさ感に与える影 響，日本建築学会計画系論文集 No.487,pp.33-41,1996.9

14）中島龍興他 2 名：照明デザイン入門、彰国社

(2006年 3 月 10 日原稿受理， 2006 年 8 月 1 日採用決定） 